\title{
大腸低分化腺癌における予後因子の検討
}

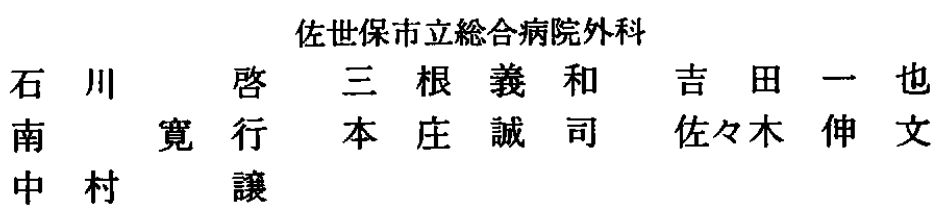

\section{A Study of Prognostic Factors in Poorly Differentiated Adenocarcinoma of the Colon}

\author{
Hiroshi ISHIKAWA, Yoshikazu MINE, Kazuya YOSHIDA, \\ Hiroyuki MINAMI, Seiji HONJO, Nobufumi SASAKI \\ and Yuzuru NAKAMURA \\ Department of Surgery, Sasebo Municipal General Hospital
}

\begin{abstract}
大腸低分化腺癌における予後規定因子について検討した。対象症例は1982年から1996年までの初発大腸癌手術 例922例中, 低分化腺虚の28例である。治痖切除症例16例の中で11例は無再発生存中であり，5例は再発死亡した。 両群間の背景因子では, 占居部位, 肉眼型, 壁深達度, リンパ節転移, 血管侵襲で有意差を認めず,リンパ管侵

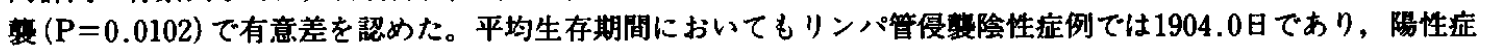
例の767.9日と比較して有意に生存期間の延長を認めた $(\mathrm{P}=0.0214)$ 。以上よク, リンパ管侵襲は大腸低分化腺癌 の予後を规定する因子となりうると考えられた。
\end{abstract}

索引用漂 : 大晹癌 (colorectal cancer), 低分化腺癌 (poorly differentiated adenocarcinoma), 予後因子 (prognostic factor), リンパ管侵撉 (lymphatic invasion)

\section{粕 $\overline{\mathbf{y}}$}

大腸癌は大部分が高分化腺癌, 中分化腺癌の分 化型癌で, 低分化腺癌の頻度はまれである。また, その治療成績については高分化，中分化腺癌と比 較して予後不良であるとした報告は多数認められ るが，低分化腺癌の中で予後因子を検討した報告 は, 症例数が少ないためか, わずかに散見される にすぎない。そこで今回われわれは，大腸低分化 腺癌における予後を規定する因子について検討し たので報告する。

\section{対象および方法}

1982年から1996年12月までに佐世保市立絵合病 院外科において手術がなされた初発大腸癌は922 例であり，この中で大腸癌取扱い規約りにしたが って, 最大割面の標本上で面積的に最も優勢な組 織像で低分化腺癌と診断された 28 例 (3.0\%) を对 象とした。对象症例の背景因子をTable. 1 に示し た。性別は男性16例，女性12例で，平均年柃は $65.6 \pm 12.2$ 歳, 占居部位は結腸が18例, 直腸が10 例であった。壁深達度はmp 1例, ss 16例, se 9 例, si 2 例であった。肝転移陽性が 4 例, 腹膜播 種陽性は 7 例で, リンパ節転移陽性が17例, 陰性 
は11例，リンパ管侵襲陽性が20例，陰性が 8 例で あった。根治度は根治度Aの治㓡切除が16例, 根治 度B，Cの非治癔切除が12例であった (Table. 1)。 なお統計学的有意差の検定には $x^{2}$ 検定, 生存率は Kaplan-Meier 法で算出し, 有意差検定はLogrank法を用いてP<0.05を有意差ありとした。

\section{成数}

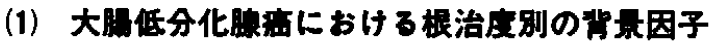

大腸低分化腺癌において, 治瘾切除, 非治瘾切 除の根治度別の臨床病理学的背景因子を検討し た。その結果Table.2で示したように占居部位, 壁 深達度, リンパ節転移、リンパ管侵襲, 血管侵讋 のすべての因子において有意差を認めた。すなわ ち, 占居部位では結腸癌で治痖切除が, 直腸癌で は非治瘾切除が多く, 壁深達度では, ssより浅いと 治虑切除が、またse以深では非治痖切除が多く有 意差を認めた。リンパ節転移では, リンパ節転移 陰性では治瘾切除が多く, 転移陽性では非治瘦切 除が多く, リンパ管侵襲では, 陰性の8例はすへ て治源切除であり，陽性例では20例中12例の60\% が非治痖切除であった。血管侵襲においても，陰 性例で治瘾切除例が多く, 陽性例で非治應切除例 を多く認めた（Table. 2 )。

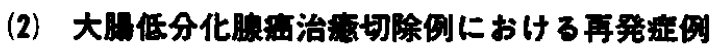
大腸低分化腺癌治癒切除例16例における再発例 は 5 例で，その予後は 9 力月から34カ月の間でい ずれも原病死であった (Table. 3$)$ 。全例結腸癌で, 壁深達度はss以深，リンパ節転移陽性例が 3 例で, リンパ管侵襲は全例で陽性であった。再発形式は,

Table. 1 Clinicopathologic analysis of 28 patients with poorly differentiated adenocarcinoma of the colon and rectum

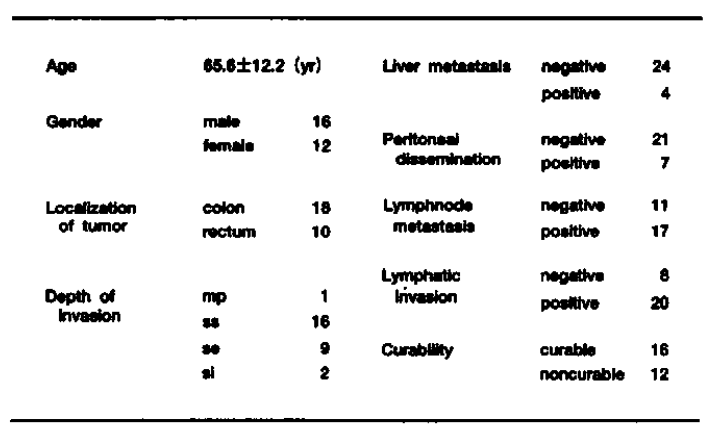

肝転移再発が 2 例, 局所再発, リンパ節再発, 腹 膜再発がおのおの 1 例であった。再発症例の予後 は, 9 カ月から 34 力, 平均20カ月で死亡した。

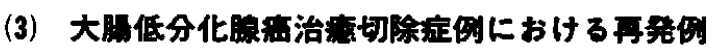
と非再発倒の青沓因子

大腸低分化腺癌治瘾切除症例16例における再発 死亡例 5 例と, 非再発生存例11例の䧗床病理学的 な背景因子を検討とした。占居部位，壁深達度， リンパ節転移，血管侵襲では両群間にまったく有 意差を認めなかったが,リンパ管侵襲で $\mathrm{P}=$ 0.0102 と有意差を認めた。すなわち, 再発例は 5 例すべてがリンパ管侵襲陽性であり，逆にリンパ 管侵襲陰性の 8 例はすべて非再発生存中の症例で あった（Table.4)。

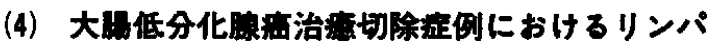

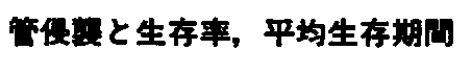

大腸低分化腺癌治癁切除症例16例におけるリン パ管侵襲と生存率, 平均生存期間の関係を検討し

Table. 2 Comparison of clinicopathologic factors between the curative and noncurative resections

\begin{tabular}{|c|c|c|c|c|}
\hline & & $\begin{array}{c}\text { Curattve } \\
(n=16)\end{array}$ & $\begin{array}{c}\text { Noncurative } \\
(n=12)\end{array}$ & p value \\
\hline $\begin{array}{l}\text { Locallzation } \\
\text { of tumor }\end{array}$ & $\begin{array}{l}\text { colon } \\
\text { rectum }\end{array}$ & $\begin{array}{r}13 \\
3\end{array}$ & $\begin{array}{l}5 \\
7\end{array}$ & $p=0.0386$ \\
\hline $\begin{array}{l}\text { Depth of } \\
\text { invasion }\end{array}$ & $\sim$ & $\begin{array}{r}13 \\
3\end{array}$ & $\begin{array}{l}4 \\
8\end{array}$ & $p=0.0142$ \\
\hline $\begin{array}{l}\text { Lymphnode } \\
\text { metaetesis }\end{array}$ & $\begin{array}{l}\text { negrtive } \\
\text { poeitive }\end{array}$ & $\begin{array}{l}9 \\
7\end{array}$ & $\begin{array}{r}2 \\
10\end{array}$ & $p=0.0898$ \\
\hline Lymphatic & $\begin{array}{l}\text { negative } \\
\text { positive }\end{array}$ & $\begin{array}{l}8 \\
8\end{array}$ & $\begin{array}{r}0 \\
12\end{array}$ & $p=0.0020$ \\
\hline $\begin{array}{l}\text { Vascular } \\
\text { invesion }\end{array}$ & $\begin{array}{l}\text { negretive } \\
\text { positure }\end{array}$ & $\begin{array}{r}12 \\
4\end{array}$ & $\begin{array}{l}3 \\
9\end{array}$ & $p=0.0150$ \\
\hline
\end{tabular}

Table. 3 Recurrent cases in curative resections with poorly differentiated adenocarcinoma of the colon and rectum

\begin{tabular}{|c|c|c|c|c|c|c|c|c|c|}
\hline & As & Condior & 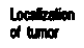 & andis of & Lymplocto & Lyentele & Alannenes & sinum & $\begin{array}{l}\text { Suniod } \\
\text { intured (nol) }\end{array}$ \\
\hline 1. & 73 & tomalo & $\mathbf{T}$ & $\boldsymbol{\bullet}$ & 1 & 1 & loced & Dind nith & 14 \\
\hline 2. & 60 & tomels & $A$ & $\approx$ & 2 & 2 & Lymphoode & 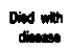 & 9 \\
\hline 3. & 61 & terness & $\mathbf{s}$ & मे & 0 & 2 & thesecte & ond with & 34 \\
\hline 4 & 99 & male & $\mathbf{s}$ & $\mathbf{w}$ & 2 & 2. & 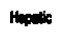 & Dod & 18 \\
\hline 5. & 73 & malo & $\boldsymbol{T}$ & $*$ & 0 & 2 & Pownown & ond & 25 \\
\hline
\end{tabular}


た。経過観察期間は 1 年 6 力月から 15 年 9 力月, 平均追跡期間は 5 年 9 力月であった。リンパ管侵 襲陽性例 8 例の 1 年生存率 $87.5 \%, 2$ 年生存率 $60.0 \%, 3$ 年生存率 $22.5 \%$, 平均生存期間767.9日 に对して、リンパ管侵襲陰性例 8 例では 1 年生存 率， 2 年生存率， 3 年生存率ともに $100 \%$ であり， 平均生存期間は 1904.0 日で, $\mathrm{P}=0.0214$ と有意に リンパ管侵襲陰性例の平均生存期間が良好であっ た (Fig. 1)。

\section{考察}

大腸低分化腺癌は，大部分の症例が診断時にす でに進行癌の状態であり,リンパ節転移、肝転移, 腹膜播種などの因子のために非治案切除となるこ とが多い。由中ら 2 は大腸低分化腺癌の治癌切除 率を54.5\%であったと報告し, 神野ら ${ }^{3}$ も治癔切 除率は $52.3 \%$ であり，分化型腺癌の $76.2 \%$ に比べ

Table. 4 Comparison of clinicopathologic factors between the died and alive patients with poorly differentiated adenocarcinoma of the colon and rectum after curative resection

\begin{tabular}{|c|c|c|c|c|}
\hline & & $\begin{array}{c}\text { Dind group } \\
(n \rightarrow 5)\end{array}$ & $\begin{array}{c}\text { Nwo group } \\
(1 \times 11)\end{array}$ & p valuo \\
\hline $\begin{array}{l}\text { Locentionation } \\
\text { of tumor }\end{array}$ & $\begin{array}{l}\text { colon } \\
\text { rectum }\end{array}$ & $\begin{array}{l}5 \\
0\end{array}$ & $\begin{array}{l}8 \\
3\end{array}$ & $p=0.2671$ \\
\hline $\begin{array}{l}\text { Deppth of } \\
\text { inveation }\end{array}$ & $\sim \infty$ & 4 & $\begin{array}{l}9 \\
2\end{array}$ & $p=0.3005$ \\
\hline Lymphnode & $\begin{array}{l}\text { negettive } \\
\text { poestive }\end{array}$ & $\begin{array}{l}2 \\
3\end{array}$ & $\begin{array}{l}7 \\
4\end{array}$ & $p=0.0806$ \\
\hline Lymphatic & $\begin{array}{l}\text { negintive } \\
\text { powitive }\end{array}$ & $\begin{array}{l}0 \\
5\end{array}$ & $\begin{array}{l}8 \\
3\end{array}$ & $p=0.0102$ \\
\hline $\begin{array}{l}\text { Vecoculer } \\
\text { imresion }\end{array}$ & $\begin{array}{l}\text { negenture } \\
\text { positive }\end{array}$ & $\begin{array}{l}5 \\
0\end{array}$ & $\begin{array}{l}7 \\
4\end{array}$ & $p=0.2448$ \\
\hline
\end{tabular}

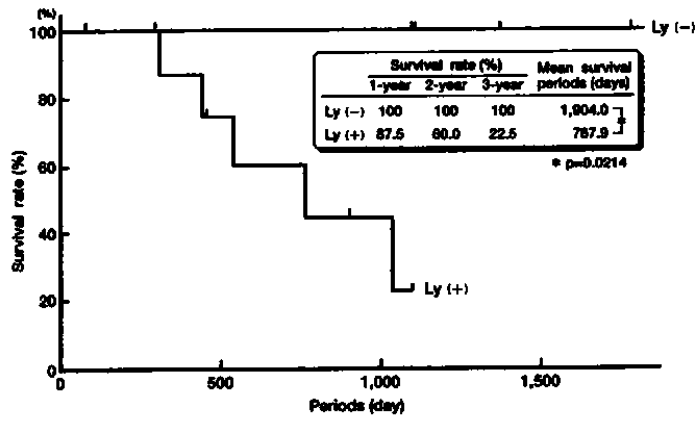

Fig. 1 Survival curves of poorly differentiated colorectal cancer after curative resection accord. ing to the lymphatic invasion
て低率であったと述べている。自験例においては, 大腸低分化腺癌28例の中で16例，57.1\%が治癔切 除例であり同様の結果であった。そこで治意切除 例と非治瘺切除例の背貫因子について検討した が，検討したすべての因子，すなわち占居部位， 壁深達度、リンパ節転移，リンパ管侵襲，血管侵 襲で有意差を認めた。つまり，占居部位が直腸で 壁深達度がse以深, リンパ節転移が陽性で,リンパ 管侵意，血管侵奬陽性例では有意に非治意切除例 が多いという結果であった。

治療切除例の予後については, 桐山ら“恃高分 化腺癌, 中分化腺癌の根治度 $\mathrm{A}$ 症例の 5 年生存率 が $89.7 \% ， 70.9 \%$ に対して，低分化腺癌では 42.9 \%と有意に不良であり，関根昼，菅野ら ${ }^{(6)}$ も同様の 結果を報告しているが，一方では神野3)，田中ら2) は治瘾切除例に限ると，分化型腺癌と低分化腺癌 の間で生存率に有意差を認めなかったと述へていい る。自鋻例においても，大腸低分化腺癌の治㾤切 除例16例の中で再発死亡例は 5 例で，その 5 生率 は $58.0 \%$ であり，高分化腺癌，中分化腺癌の 5 生 率 $68.4 \%$ と比へて有意差を認めなかった。再発形 式では，2 例が肝転移再発で局所再発，リンパ節 再発, 腹膜再発がおのおの 1 例ずつであり，分化 型腺癌と同様の再発形式であった。再発例の 5 例 はすべて結腸癌であり，壁深達度はss以深，リンパ 管侵襲が全例で陽性であった。

そこで治源切除例を無再発生存例と再発死亡例 に分けて，その背景因子を解析することで再発の 危険因子を検討した。その結果，有意差を認めた 因子はリンパ管侵襲のみであり，リンパ管侵莘陰 性の 8 例は全例が非再発生存例であり，逆に再発 死亡例の 5 例ではすべてがリンバ管侵襲陽性であ った。さらにその生存率と平均生存期間を検討す ると,リンパ管侵襲陰性例では再発死亡例はなく, その 3 年生存率は $100 \%$, 平均生存期間は 1904.0 日 であったが，リンパ管侵襲陽性例では 3 年生存率 は $22.5 \%$, 平均生存期間は767.9日であり, 平均生 存期間において $\mathrm{P}=0.0214$ で有意差を認めた。大 腸低分化腺癌における予後因子としてのリンパ管 侵曫の報告は，今回検索した範囲では見あたらな かったが、長谷ら”は, 大腸癌の浸潤增殖侎式 (INF)の予後因子としての意義に関する検討で, 
INFは癌細胞の組織間吵への浸潤とともに明確な リンパ管侵襲を含むものであり，癌の悪性度や浸 潤に関する旺盛な生物学的態度を表し，大腸癌の 予後規定因子として有用な指標であると述へててい る。大腸低分化腺癌に限った予後因子の報告では, 組織学的な亜分類を用いた報告が散見される。す なわち, 重松ら カルチノイド型, 低分化腺癌型, 粘液細胞型に分 け，充実胞巣型で予後良好であるが，低分化腺癌 型, 粘液細胞型で予後不良であったと述へている。 また, 大塚ら”は間質の結合織の多璂により，結合 織が少ない順に䯣様型 (medullaly type以下 med), 中間型 (intermediate type以下int), 硬性 型 (scirrhous type以下sci)に分類し, medに比へ てint, sciではリンパ管侵襲、リンパ節転移，腹膜 播種が多く予後は有意に不良であったと述べてい

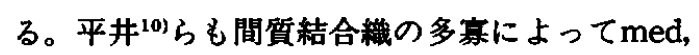
int, sciに分けて検討し, 5 年生存率はmedで79.6 \%と良好であり, sciには 3 年生存例はなく有意差 を認めたと報告し，この間質別の予後の差は，リ ンパ管侵襲、リンパ節転移, 治虑切除率に大きな 影整を受けていたと述へている。自涘例において も大腸低分化腺癌を間質結合織の多寒によって覀 分類し, medとintの間で生存期間を比較すると, 有意差は認められないもののmedの平均生存期間 が良好であった。大塚"，平井ら ${ }^{10)}$ も述べているよ うに, 間質結合織とリンバ管侵襲の間には密接な 関連があり，リンパ管侵襲が予後規定因子として 有用であることを間接的に証明しているものと考 えられた。

分化型腺癌と比較した場合, 大腸低分化腺癌の 治療成䌙は不良であり，たと之治瘾切除例であっ てもリンパ管侵襲陽性の危険因子を有する症例に おいては, 術後の強力な補助化学療法が必要であ ることは言うまでもない。今後，大腸低分化腺癌 の治療成綪向上のためには，症例に応した危險因 子を考虑した集学的治療が不可欠であると考えら れた。

\section{結語}

大腸低分化腺癌28例の中で治瘦切除症例16例 を, 再発死亡例の 5 例と非再発生存例の11例に分 け, 䠦床病理学的な予後規定因子を検討した。そ の結果, リンパ管侵襲で $\mathrm{P}=0.0102$ と有意差が認 められ，予後規定因子として有用であることが明 らかとなった。さらに治瘾切除症例16例をリンパ 管侵襲の有無によって 2 群に分け，その生存率と 平均生存期間を検討したところ, 平均生存期間に おいてリンパ管侵襲陰性症例は陽性症例に比べて $\mathrm{P}=0.0214$ で有意に平均生存期間の延長が認めら れた。

\section{卷帣文部}

1）大腸癌研究会編：大腸癌取扱い規約. 改訂第 5 版. 金原出版, 東京, 1994

2）田中千额, 大下裕夫, 㳭田代造 : 大腸低分化腺癌 の臨床病理学的検討. 日臨外医会誌 $53: 313-317$, 1992

3）神野正博, 坂本浩也, 月岡雄治他：大䁑低分化腺 癌の臨床病理学的研究. 日本大腸肛門病会誌 45 ： 244-247, 1992

4）桐山正人, 黒阪慶幸, 松下昌弘他：大腸低分化腺 癌の臨床病理学的研究. 消化器癌 $6: 37-41,1996$

5）関根 媇, 柿沼臣一：大陽低分化腺癌の臨床病理 学的研究. 癌の臨39:485-490, 1993

6）皙野圭一, 大和田 進、森下靖雄：大腸低分化腺 癌・印鑑細胞癌症例の検討. 日臨外医会誌56： 1806-1810, 1995

7）長谷和生, 望月英隆, 宇都宮勝之他：大腸癌の浸 洞增殖様式（INF）の予後規定因子としての意義 に関する検討. 日本大腸肛門病会誌49：463-469, 1996

8）重松明博：低分化型大腸癌の臨床病理学的研究. 病理と研究 $3: 1239-1249,1985$

9）大塚正彦, 加藤 洋：大腸の低・未分化癌の䧗床 病理学的検討一分類および内分泌細胞癌との関 連について. 日消外会誌25：1248-1256, 1992

10）平井一郎, 池田栄一, 飯澤他：大晹低分化腺 癌, 印篮細胞疾の稪床病理学的検討. 日消外会誌 $28: 805-812,1995$ 